\title{
ASSESSMENT OF IMMUNOCHROMATOGRAPHIC TEST FOR RAPID LYMPHATIC FILARIASIS DIAGNOSIS
}

\author{
NGUYEN N.L.*, PLICHART C.** \& ESTERRE P.***
}

\section{Summary :}

Two rapid immunodiagnostic tests (ICT Filariasis test ${ }^{\circledR}$ ), developed for the quick diagnosis of Wuchereria bancroffi infection, have been validated in laboratory and field situation. The aim of this study was to assess the performance and usefulness of this antigen capture assay as a diagnostic method in three foci of lymphatic filariasis, located in the South Pacific (Society archipelago, French Polynesia), with different levels of endemicity. A sample of 1,595 patients was tested with this assay in parallel with a reference $\mathrm{Og} 4 \mathrm{C} 3$ antigen capture assay and microfilariae detection. A second-generation ICT test, available for whole blood analysis, was also tested in parallel with the first generation test, developed for serum analysis, on a sample of 50 reference cases. The correspondence between the results obtained with the two rapid tests was excellent, without any influence of rheumatoid factors, but the sensitivity was in both cases slightly inferior to the one obtained with the ELISA reference test. This seems particularly true in epidemiological situation where a high proportion of amicrofilaraemic, adult worm carriers are observed.

KEY WORDS : lymphatic filariasis, Wuchereria bancroffi, rapid antigen capture assay, ICT Filariasis test, French Polynesia.

MOTS CLÉS : filariose lymphatique, Wuchereria bancrofti, test rapide d'immunocapture, test "ICT Filariose", Polynésie Française.
Résumé : VALIDATION DE TESTS IMMUNOCHROMATOGRAPHIQUES POUR LE DIAGNOSTIC RAPIDE DE LA FILARIOSE LYMPHATIQUE

Deux tests d'immunodiagnostic rapide de la filariose à Wuchereria bancrofti (kits australiens ICT Filariose ${ }^{\circledR}$ ) ont été étudiés sur le terrain et au laboratoire. Le but de cette étude était de vérifier les performances et l'utilité réelle de ces tests de capture d'antigène dans la filariose lymphatique dans trois foyers d'endémicité différente, situés dans l'archipel de la Société (Polynésie Française). Un échantillon de 1595 patients a donc été analysé en parallèle avec le test ICT, la technique ELISA de référence (capture de l'antigène circulant $\mathrm{Og} 4 \mathrm{C} 3$ ) et la détection de microfilaires sanguines (par filtration sur membrane Nucléopore ${ }^{\circledR}$ ). Une seconde génération de test, validée pour l'utilisation de sang total, a été testée en parallèle sur une cinquantaine de sérums de référence, par rapport au test de première génération, validé sur le sérum uniquement.

La correspondance entre les résultats obtenus par les deux tests rapides est excellente mais la sensibilité de cette technique immunochromatographique est toujours inférieure à celle de l'ELISA de référence. Contrairement à un test équivalent de diagnostic rapide du paludisme (ICT Malaria Pf ${ }^{\circledR}$, il ne semble pas y avoir de faux positifs dus à la présence de facteurs rhumatoïdes. La performance inférieure par rapport à l'ELISA semble accentuée dans les situations épidémiologiques où l'on observe une forte proportion d'individus amicrofilarémiques mais porteurs de vers adultes, comme dans certaines îles du Pacifique soumises à un contrôle de masse depuis de nombreuses années.
$\mathrm{R}$ ecent recommendations by WHO suggest that endemic countries for lymphatic filariasis must consider testing rapid and simple (card-test format) assays in place of enzyme-linked immunosorbent (ELISA) or parasitological detection of microfilaria (Ottesen, 1994; Ottesen et al., 1997).

As an independent laboratory with a long-term experience of diagnosis of lymphatic filariasis, including about ten thousands ELISA assays for detecting adult worm circulating antigens, we organized a trial of two

\footnotetext{
* Epidemiology Unit and

** Immunology Unit, Institut Territorial de Recherches Médicales Louis Malardé, BP 30, Papeete, 98713 Tahiti (French Polynesia). Correspondence: Dr Philippe Esterre, Head of Immunology Unit. Fax: 689431590 - E-mail: esterre@malarde.pf

Informations on the Filariasis research program can be found at: http://www.malarde.pf
}

new (first- and second-generation) rapid immunochromatographic tests under carefully controlled field and laboratory situations.

\section{MATERIAL AND METHODS}

\section{SERUM SAMPLES}

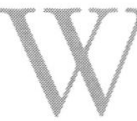
e used 399 reference sera of inhabitants from Tahaa island, collected during a recent survey organized after four years of annual bitherapy with diethylcarbamazine (DEC) and ivermectin (IVM) (see Moulia-Pelat et al., 1995), and 200 reference sera from Opoa island, after six years of semiannual chemotherapy with IVM (Nguyen et al., unpublished data). In addition, 996 reference sera, taken 
from all inhabitants of Maupiti island where filariasis endemic is at very low level, were used. At the 1997 end-point, the epidemiological situation in Tahaa, Opoa and Maupiti islands was quite different (see Table II).

\section{METHODS}

Following the manufacturer's recommendations, analysis was performed on all samples for the antigenemia with a commercial (TropBio, JCU Tropical Biotech. Ltd., Townsville, Australia) ELISA assay using an IgM (called Og4C3) monoclonal antibody (Chanteau et al., 1994, Simonsen et al., 1996), and with the rapid immunochromatographic test (ICT Filariasis ${ }^{\circledR}$, ICT Diagnostics Ltd., Brookvale, Australia) developed for serum analysis (first generation tests: Freedman et al., 1997; Weil et al., 1997) and using a monoclonal antibody called AD12.1 (Weil et al., 1987). Subsequently, on a sub-sample of 50 randomly selected sera, a second generation test (ICT Filariasis Whole Blood Test ${ }^{\circledR}$ ) was performed in parallel with the first generation test (ICT Filariasis ${ }^{\circledR}$ ). All samples were marked in code and tested without knowledge of previous test results. Ten rheumatoid factor positive sera, as determined by direct haemagglutination (Rhumalatex ${ }^{\circledR}$ kit, Fumouze lab., Levallois, France) were tested with the ICT test in order to check for the possibility of false positivity due to autoantibody formation (Grobusch et al., 1999). All discordant results between the quick test and the ELISA assay were checked by a second round of ICT testing.

\section{STATISTICAL ANALYSIS}

The variation between the card-test and the ELISA assay was determined by calculating Kappa ( $\kappa$ ) values with $95 \%$ confidence intervals. The $\kappa$ values between 0.60 and 0.80 were considered as good, and $\kappa>0.81$ as very good agreement beyond chance (Buhrer et al., 1998). The McNemar's chi-square test, based on the number of discordant pairs, was used to test for differences in the results of the standard (ELISA) and rapid
(ICT) tests, and between the first- and second-generations ICT tests, according to the different groups. The sensitivity and specificity of the ICT tests were determined using the Og4C3 ELISA as the reference test.

\section{RESULTS}

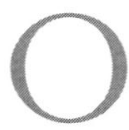
$\mathrm{n}$ the basis of the microfilaremia only (Nucleopore membrane filtration technique of $1 \mathrm{ml}$ of venous blood), the sera can be classified in two groups: amicrofilaremic and microfilaremic patients. If we also consider the results of the ELISA assay detecting the circulating $\mathrm{Og} 4 \mathrm{C} 3$ antigen, the sera can be classified into three groups (Nicolas, 1997): microfilaremic patients, positive with both tests; amicrofilaremic "adult worm carrier" patients, with only a positive antigenemia; and negative controls. On the basis of epidemiological data, the sera were also classified following the degree of endemicity of the corresponding island.

The results of the initial analysis using the whole sample (1595 sera) are shown in Table I. A quite good degree of global agreement $(92.4 \%)$ was observed between the ELISA and the card-test but a significant difference was observed between these two tests $\left(\mathrm{McNemar} \mathrm{Chi}^{2}=49\right.$, $p<0.0001)$. The agreement beyond chance was clas-

\begin{tabular}{ccccc}
\hline & & \multicolumn{3}{c}{ Og4C3 ELISA } \\
\cline { 3 - 5 } & & Positive & Negative & Total \\
\hline \multirow{3}{*}{ Card-Test } & Positive & 104 & 22 & 126 \\
& Negative & 99 & 1,370 & 1,469 \\
\hline & Total & 203 & 1,392 & 1,595 \\
\hline
\end{tabular}

The agreement was $92.4 \%$ with a kappa value of $0.60(\mathrm{SE}=0.05$, $p<0.0001$ ).

Table I. - Comparison between the ELISA and the ICT test results for the detection of circulating antigen of Wuchereria bancrofti.

\begin{tabular}{|c|c|c|c|c|c|c|c|}
\hline & \multirow[b]{2}{*}{$\begin{array}{c}\text { Microfilar prevalence } \\
(\%)\end{array}$} & \multicolumn{2}{|c|}{ Og $4 \mathrm{C} 3$ antigen } & \multirow[b]{2}{*}{$\begin{array}{c}\text { Adult worm carriers } \\
(\%)\end{array}$} & \multicolumn{3}{|c|}{ ICT card-test results } \\
\hline & & $\begin{array}{l}\text { Mean } \\
\text { level }^{a}\end{array}$ & $\begin{array}{l}+ \text { ve } \\
(\%)\end{array}$ & & $\begin{array}{l}+\mathrm{ve} \\
(\%)\end{array}$ & $\begin{array}{c}\text { False + ve } \\
(\%)\end{array}$ & $\begin{array}{c}\text { False - ve } \\
(\%)\end{array}$ \\
\hline Hyperendemic focus ${ }^{c}$ & 12.7 & 328.6 & 27.1 & 21.9 & 19.0 & 1.5 & 9.5 \\
\hline Mesoendemic focus ${ }^{\mathrm{d}}$ & 3.5 & 369.7 & 26.0 & 25.1 & 13.0 & 0.05 & 14.5 \\
\hline Hypoendemic focus ${ }^{\mathrm{e}}$ & 0.4 & 37.1 & 4.1 & 3.4 & 2.4 & 1.5 & 3.2 \\
\hline
\end{tabular}

${ }^{a}$ Mean level of circulating Og4C3 antigen, expressed in UI/mL; ${ }^{\mathrm{b}}$ Amicrofilareamic, adult worm carriers; ${ }^{\mathrm{c}} 1997$ survey in Tahaa island, after four years of DEC+IVM; ${ }^{\mathrm{d}} 1997$ survey in Opoa island, after six years of IVM; ${ }^{\mathrm{e}} 1997$ survey in Maupiti island, after 30 years of DEC.

Table II. - Results of the ELISA and ICT test for the detection of circulating antigen of Wuchereria bancrofti, according to three endemic levels in Pacific islands. 
sified as good, at the inferior limit $(\kappa=0.60)$. In comparison with the ELISA reference test, the sensitivity and specificity of the ICT test were $51.2 \%$ and $98.4 \%$, respectively. The results of ICT testing in the three endemic situations (hyperendemic in Tahaa, mesoendemic in Opoa and hypoendemic in Maupiti) are shown in Table II. A non negligible proportion of false negative results was noted, especially in situation with a high prevalence of amicrofilaraemic, adult worm carriers (14.5\% of false negative results in the Opoa cohort, where $26 \%$ of the sample is made of such adult worm carriers). It is interesting to notice that the mean level of antigenemia in these false negative $\left(\mathrm{Og} 4 \mathrm{C}^{+}, \mathrm{ICT}^{-}\right)$sera $(533.7$ $\pm 402.8 \mathrm{UI} / \mathrm{mL}, n=32$ ) was significantly $(t=6.34$, $p<0.0001$ ) lower than the one observed in the sample of $\mathrm{Og} 4 \mathrm{C}^{+}$sera $(1,082.5 \pm 603.2 \mathrm{UI} / \mathrm{mL}, n=203)$. Consequently the degree of agreement with the ELISA data was the lowest $(72.5 \%)$ in the Opoa cohort, by comparison with the Tahaa and the Maupiti cohorts ( $90.0 \%$ and $95.3 \%$ of agreement, respectively). Similarly, the sensitivity and specificity were respectively $64.8 \%$ and $97.9 \%$ in Tabaa; $46.3 \%$ and $99.3 \%$ in Opoa; and $21.9 \%$ and $98.4 \%$ in Maupiti. Although the specificity of ICT test remained very good in all endemic situation, its sensitivity decreased (although not significantly) when the microfilarial prevalence decreased. According to the parasitological data, the degree of agreement with ELISA was good in both the microfilaremic and the amicrofilaremic group (data not shown). On the sub-sample of 50 reference sera, the agreement observed between the first-generation (serum-based) and the second-generation (whole blood-based) card tests was perfect $(100 \%)$. No rheumatoid factor-positive sera were positive with the ICT test.

On a practical basis, the card-test was very simple and straightforward to perform and seemed appropriate for a non-specialist laboratory, even in field conditions where small numbers of sera are generally to be tested every day. According to the manufacturer's recommendations it seems better to store kits at +2 to $+8{ }^{\circ} \mathrm{C}$, even if the shelf life at $+25^{\circ} \mathrm{C}$ is at least of six months, so refrigeration is recommended even if not absolutely necessary.

\section{DISCUSSION}

T $\mathrm{n}$ order to evaluate the reliability of new rapid tests under local conditions, including different levels of 1 parasitemia, we tested stored sera from three carefully managed human cohorts using the card-test and the standard ELISA assay. If the agreement between the two ICT tests (serum based- and whole blood basedtests) was good, their decreased sensitivity by comparison with the ELISA-based reference test was impai- ring their use for individual diagnosis. In particular, it seems that the sensitivity of the ELISA ( $67 \%$ in a brazilian focus, see Rocha et al., 1996) and the ICT (about $56 \%$ in our polynesian focus) tests for detecting adult worm carriers is not perfect. Consequently, ICT tests can be better used to monitor at the population level the efficiency of filariasis control strategy, since we know that antigenemia decreased when control strategy is correctly conducted, according to our monitoring experiences of some pilot areas in French Polynesia (Moulia-Pelat et al., 1995; Nicolas, 1997).

Regarding the filariasis control programs recommended in different endemic areas by WHO, it is matter of great importance to assess their impact (WHO, 1996, 1998; Ottesen et al., 1997). Because laboratory facilities are not always available in endemic areas, and, moreover, because the standard techniques (ELISA, even when using a filter-paper version (Simonsen \& Dunyo, 1999) or membrane filtration technique) are expensive and time-consuming, the use of ICT kits appears as a rapid and adequate tool, easy to perform, for the determination of filarial infection prevalence (Weil et al., 1997). This technique allows blood or plasma analysis in less than 15 minutes, and they can be taken day or night, which is logistically preferable. However, when testing sera from a focus with controlled transmission (i.e. with a low level of microfilaremia associated to high level of antigenemia, including a non negligible proportion of amicrofilaremic, adult worm carriers), there was an increasing risk of false negative results and the test was considered less useful in this peculiar situation. This could lead to a problem for stopping control programmes, as appropriate endpoints could be more difficult to define than previously thought.

\section{ACKNOWLEDGEMENTS}

T The field studies in Tahaa, Opoa and Maupiti islands were supported by an UNDP/World Bank/WHO/TDR grant (Special Program for Research and Training in Tropical Diseases, award $\mathrm{N}^{\circ}$ 960660). We are indebted to Dr Xavier Deparis, Mr Herve Hascoet, Roger Eperania, Eric Fuller, Franck Tuheiava and Mrs Jeanette Mahaa for their support on the field. We are also grateful to all the inhabitants of Tahaa, Opoa and Maupiti for their collaboration.

\section{REFERENCES}

Buhrer S.S., Smits H.L., Gussenhoven G.C., Van Ingen C.W. \& KLTASER P.K. A simple dipstick assay for the detection of antibodies to phenolic glycolipid-1 of Mycobacterium leprae. American Journal of Tropical Medicine and Hygiene, 1998, 58, 133-136. 
Chanteau S., Moulia-Pelat J.P., Glaziou P., Nguyen L.N., Luquiaud P., Plichart C., Martin P.V.M. \& Cartel J.L. Og4C3 circulating antigen, a marker of infection and adult worm burden in Wuchereria bancrofti filariasis. Journal of Infectious Diseases, 1994, 170, 247-250.

Freedman D.O., De Almeida A., Miranda J., Plier D.A. \& BRAGA C. Field trial of a rapid card test for Wuchereria bancrofti. The Lancet, 1997, 350, 1681.

Grobusch M.P., Alpermann U., Schwenke S., Jelinek T. \& WARHUST D.C. False-positive rapid tests for malaria in patients with rheumatoid factor. The Lancet, 1999, 353, 297.

Mouliat-Pelat P., Nguyen N.L., Hascoet H., Luquiaud P. \& Nicolas L. Advantages of annual single dose of ivermectin $400 \mathrm{mg} / \mathrm{kg}$ plus diethylcarbamazine for community treatment of bancroftian filariasis. Transactions of the Royal Society of Tropical Medicine and Hygiene, 1995, 89, 682-685.

Nicolas L. New tools for diagnosis and monitoring of Wuchereria bancrofti parasitism: the Polynesian experience. Parasitology Today, 1997, 13, 370-375.

OTTESEN E. The human filariasis: new understandings, new therapeutic strategies. Current Opinion in Infectious Diseases, 1994, 7, 550-558.

Ottesen E., Duke B.O.L., Karam M. \& Behbehan K. Strategies and tools for the control/elimination of lymphatic filariasis. Bulletin of the World Health Organization, 1997, 75, 491-503.

Rocha A., Addiss D., Ribeiro M.E., Noroes J., Baliza M., Medeiros Z. \& Dreyer G. Evaluation of the Og4C3 ELISA in Wuchereria bancrofti infection: infected persons with undetectable or ultra-low microfilarial densities. Tropical Medicine and International Health, 1996, 1, 859-864.

Simonsen P.E., Lemnge M.M., Msangeni H.A., Jakobsen P.H. \& Bygbjerg I.C. Bancroftian filariasis: the patterns of filarial-specific immunoglobulin G1 (IgG1), IgG4 and circulating antigens in an endemic community of northern Tanzania. American Journal of Tropical Medicine and Hygiene, 1996, 55, 69-75.

Simonsen P.E. \& Dunyo S.K. Comparative evaluation of three new tools for diagnosis of bancroftian filariasis based on detection of specific circulating antigens. Transactions of the Royal Society of Tropical Medicine and Hygiene, 1999, 93, 278-282.

Weil G.J., Jain D.C., Santhanam S., Malhotra A., Kumar H., Sethumadhavan K.V.P., Liftis F. \& Ghosh T.K. A monoclonal antibody-based enzyme immunoassay for detecting parasite antigenemia in bancroftian filariasis. Journal of Infectious Diseases, 1987, 156, 350-355.

Weil G.J., Lammie P.J. \& Weiss N. The ICT Filariasis test: a rapid-format antigen test for diagnosis of bancroftian filariasis. Parasitology Today, 1997, 13, 401-404.

WHO. Strategies for control of lymphatic filariasis infection and disease: report of a WHO/CTD/TDR consultative meeting, Penang, Malaysia, 22-24 August 1994. Geneva, WHO, Doc. TDR/CTD/FIL/PENANG/94.1.

WHO. Lymphatic Filariasis. Geneva, WHO Fact Sheet 190, January 1998.

Reçu le 11 mai 1999

Accepté le 2 septembre 1999 